\title{
LEGAL PROTECTION ON INDONESIAN LABOR IN ABROAD
}

\author{
Arpangi \\ Sultan Agung Islamic University, Semarang \\ arpangi@unissula.ac.id
}

\begin{abstract}
The number of cases of migrant workers abroad need to establish protection which is able to overcome the problems or issues that have so far linked with the placement and protection of migrant workers, both before leaving for work and after returning to Indonesia. As stipulated in the Act no. 392004 Article 6 that the government is responsible for enhancing the protection of migrant workers abroad, so here takes an active role from the government on how to protect workers without pressure from other parties. In order to protect workers, it is also require the participation of various parties, such as the family of migrant workers, labor organizations, and other parties that exist. In order to provide protection to workers, it is not only the duty of the minister of labor alone, but also the duty of the foreign minister. This is in accordance with the wording of Article 19 (b) of Law No. 37 of 1999 on Foreign Relations, which is representative of the Republic of Indonesia is obliged to provide care, protection and legal aid to citizens and legal entities abroad Indonesia in accordance with national legislation and international law and practice.
\end{abstract}

\section{Keywords: Legal Protection; Indonesian Workers, foreign countries}

\section{A. INTRODUCTION}

In the development of today's world, Indonesia is included as a developing country, thus it experiences a problem of population. Every year the population is significantly increase in Indonesia, so it is very influential on the addition of manpower. Besides, what happened in Indonesia economic growth is still weak and its prospect is not yet clear, to what point our county will become? Although the data show economic growth of $5.8 \%$ per year, it is actually supported mainly by household consumption, which in the long term cannot be expected to grow higher, especially the government budget cannot be expected much because of the huge burden of government debt.

From these limitations, the economic rate in Indonesia is very dependent on the business world, namely export and investment. In order to address economic growth and employment the Indonesian government has tried to attract foreign investors to invest in Indonesia. In fact, to overcome one of the problems in Indonesia, namely the problem of employment and unemployment, then what is needed is the investment or the move of 
the real sector where currently it is not seen any good prospects. With the undeveloped of the real sector and investment causes the increasing the number of unemployment, this is because the availability of employment with the number of existing labor is unbalanced.

Although various ways have been done by the Indonesian government, in fact it is not yet able to overcome the problems of employment. It is proven that there are many unemployment everywhere. Investors are reluctant to invest in Indonesia because among others:
a. Legal certainty
b. Security
c. Smuggling
d. Tax manipulation
e. Corruption
f. Levies

g. Other specific issues such as industrial relations disputes and strikes, regional autonomy etc. ${ }^{1}$

With so many unemployment in Indonesia, hence it causes the job seeker to migrate, they migrate from one area to another area and even migrate to abroad. They migrate abroad because in abroad is relatively big wage system compared to in Indonesia, so they volunteer to work abroad. With the existence of labor migrants abroad, the Indonesian government is much benefited, because in addition to reducing the number of unemployed, it can also bring in foreign exchange for Indonesia, even formerly called the heroes of foreign exchange.

Not all dreams or expectations can be achieved perfectly, it is also experienced by many of our workers who migrate abroad, such as to Malaysia, Brunei, Saudi Arabia Etc. In these destination countries, many of our labor-power workers experience problems, such as being mistreated by the employer. For example, the case of Sumiati from Dompu Sumbawa Nusatenggara Barat, the master cut her lips. Kikin Komala Sari from Cianjur West Java who was killed and her corpse thrown in the trash. These cases are only two of 41,736 cases of labor migrants in the Middle East region recorded by puslitfo BNP2TKI in the period January 1 to November $1,2010 .{ }^{2}$

\footnotetext{
${ }_{1}$ Masrana sama, SH. Paper In Search of a Better Industri Relations System for Indonesia. Bandung 2 Desember 2006.

${ }^{2}$ Kompas 26 November 2010
} 
The biggest problems experienced by Indonesian workers abroad are in Saudi Arabia with 27,196 cases, United Arab Emirates 5,686 cases, Qatar 2,317 cases, Kuwait 2,254 cases, Oman 1,835 cases, Jordanian 1,013 cases, Bahrain 601 cases. Of the tens of thousands of cases of migrant workers in Saudi Arabia 2,114 were cases of ill-treatment, 1,709 cases of sexual harassment, 7,197 cases of labor-related illness, 1,475 unpaid salaries, 8,581 cases of unilateral dismissal ${ }^{3}$. In order to protect migrant workers not only after they are abroad, but also cover at the time the prospective migrant worker is still in Indonesia. As Article 1 paragraph (4) states "the protection of labor migrants shall be all efforts to protect the interests of prospective labor migrants or labor migrants in realizing the guaranteed fulfillment of their rights in accordance with legislation, before, during, or after work". So the protection of labor migrants starting from the initial process, namely from recruitment in the country until later returned to Indonesia. Because so far there is also undue treatment done by people associated with the migrant workers, such as the prospective migrant workers many who abandoned before dispatched, even after returning home in Indonesia again there are also frauds committed by people who do not to be responsible.

From many cases of migrant workers abroad, it needs to be protections that can overcome the problems exist so far related to the placement and protection of Indonesian workers before leaving, during work and after returning to Indonesia. Therefore, it needs a mutual coordination between related institutions from the Regional Government, the Department of Manpower and Transmigration, the National Agency for the Placement and Protection of Indonesian Migrant Workers (BNP2TKI), the Department of Foreign Affairs to avoid overlap of authority and mutual tug of power between institutions. Thus, we can monitor every step of the migrant worker, so if there are problems related to the TKI, it can be traced to the location of the error. Therefore, it can be known to be the responsibility of who and will not happen to blame each other between institutions.

From these various labor issues, it is caused by the lack of attention paid to labor issues, especially for developing countries that send their workforce abroad or from the country of employment. Lack of attention, lack of protection are not only because the attention of the overseas labor sending country is focused on domestic problems, but also because the problems of violations in the workplace are more likely to be closed from public access and the dilemma of the labor force itself fight for his rights.

\footnotetext{
${ }^{3}$ Ir. Norbertus Kaleka, Suara Merdeka, 19 November 2010.
} 
Based on the above description of the many cases experienced by abroad workers, it needs to be discussed about 'the role of the Indonesian government in protecting Indonesian workers abroad'. Since so far there has been no handling of the problems of migrant workers maximally. Maximum service here can also happen while they are still in Indonesia, so we limit the problems that occur when the workers are abroad.

\section{B. DISCUSSION}

After the monetary crisis in 1997, many companies, both domestic and foreign companies were closed down, so that many of them closed the business. With the many industries stopped their business, it will cause the number of unemployed as a result of the dismissal that occur everywhere. It will cause a lot of unemployment, since looking for work was very difficult, so many of them decided to work overseas. It was also triggered because working abroad will get a reward or a large wage.

Abroad Workers are referred to as migrant workers, means a person who works in a State where he is not a resident of the State where he/she is working for a relatively long period of time ${ }^{4}$. This migrant worker is also referred to as TKI which is every Indonesian citizen who is eligible to work abroad in working relationship for a certain period of time by receiving wages (Article 1 point 1 of Act No. 39 of 2004 concerning the placement and protection of TKI). Citizens working abroad the Indonesian government have a duty to protect its citizens who are abroad. In protecting migrant workers, the country faced the problems between the interests to protect citizens who are abroad with the applicable law in the country where the citizens of Indonesia are located.

The protection of a citizen of the State has two distinct jurisdictions, namely the territory of national law and jurisdiction of the receiving State or the place where the workforce is employed. Because the state's protection against those citizens has two areas, as long as the worker is still in Indonesia, if there is a violation or election against the prospective migrant worker, then Indonesia Law is applied such as Law no. 13 of 2003 , and other legislation relating to the issue. This is because the prospective migrant worker is still within the territory of the Indonesian state. However, it will be different if the prospective migrant worker is already in abroad although he/she has not yet working, then that will be applied is the law where the prospective migrant workers are located,

\footnotetext{
${ }^{4}$ Dr. Ade Maman Suherman, SH., M.Sc, Paper PerlindunganTtenaga Kerja Migran Dalam Perspektif Hukum, Seminar and Workshop Nasional Kerjasama Departeman Luar negeri and FH.UNSOED, 28 May 2009.
} 
because the law of Indonesia cannot reach them or the case is already outside Indonesian territory. Since it already involves the inter-State, in order to protect the workforce must be in accordance with international law applicable principle, so that if there are our troubled labor abroad then law enforcement to follow applicable law in the State where they are.

As regulated in the Act no. 39 of 2004 Article 6 that the government is responsible for increasing the protection of Indonesian migrant workers abroad, it is necessary the active role of the government how to be able to protect the workers without any insistence from other parties. In order to protect these workers also requires the participation of various parties, such as families of migrant workers, labor organizations, and other parties that exist. In order to provide protection to worker is not only the duty of the minister of labor alone, but also the duty of the foreign minister. This is in accordance with the Article 19 (b) of Law no. 37 of 1999 on Foreign Relations, namely the representation of the Republic of Indonesia is obliged to provide protection, protection and legal assistance for Indonesian citizens and legal entities abroad in accordance with national legislation and international law and customs.

In relation to the legal protection of migrant workers concerning the inter-state, it is necessary to have an agreement between the State of Indonesia and the State in which the worker is located. The Agreement is called an International Agreement, that is, agreements in certain forms and names stipulated in international law which are made in writing and incurring rights and obligations in the field of public law ${ }^{5}$. Since the treaty concerns the interests of the two States, the contents of the treaty must be able to harmonize the powers of the two States for common interests and purposes without prejudice to the jurisdiction of their respective States. The position of the international agreement is in the midst of the two States concerned, so it is impartial or incriminating in one of the States. Because it is related to the relationship between the two countries, what can be done by the Indonesian government is to improve diplomatic relations between the two countries. As regulated in Law no. 37 of 1999 Article 7 letter D stating that the government makes diplomatic efforts to ensure the fulfillment of the right and protection of labor migrants optimally in the destination country.

The contents of the international agreement also have limitations in the context of protecting labor migrants, this is because given the issue of protection must be

\footnotetext{
${ }^{5}$ Dit. Perjanjian Ekonomi , 2009, Sosial dan Budaya Departeman Luar Negeri.
} 
subordinate to or follow the national law of the recipient country. Thus, the treaties made by the two countries will not touch up to the root of the problem and it is not possible to directly provide protection. As we know each bilateral agreement will only record the commitments between the two countries to provide protection, so that any existing problems will still be resolved by the laws of the State where the worker is located. Protection of migrant workers can be done by the State of Indonesia only based on national law where the worker is located. In addition to improving diplomatic relations between the two countries, the Indonesian government should also ratify international conventions related to the protection of labor abroad, such as the 1990 migrant convention, so that if the Indonesian government has ratified it in providing protection to Indonesian workers who are in Indonesia alone as well as those located abroad, it can be applied internationally. Besides, ratifying the international convention, the Indonesian government is also willing to revise UU no. 39 of 2004 on the placement and protection of migrant workers abroad (PPTKILN) because the law is less able to provide protection to migrant workers who are in abroad. And no less important is the Indonesian government should review or improve the MoU with recipient countries. So what happens in Saudi Arabia's will not happen.

From the case of migrant workers under the bridge is only one picture of the problems of migrant workers abroad, it could be in Malaysia, Brunei, Kuwait and other countries also occurs such problems. From the problems of migrant workers who are under the bridge of the flag of the Government of Indonesia that the case is because the worker is running out of permission to stay. The government's explanation is very different from what is reported in various mass media, because of the problems of migrant workers are also many workers are gone from the house of the employer. This happens because the worker is treated unfairly by the employer, such as sex abuse, abuse and even torture. Besides, the news as it turns out the Indonesian government is not able to repatriate the migrant workers who live in the abroad. The incident should not happen if the Indonesian government with the Saudi Arabian government mutually improve diplomatic relations and want to see the MoU that has been agreed upon. If Mou is regarded as irrelevant and it is necessary to hold a review immediately as soon as possible to revise the Mou, so that migrant workers who are in Saudi Arabia can get maximum protection.

From the situation of overseas migrant workers mentioned above, it can provide a very bad image of our country, because the people of accepting countries will see that the 
Indonesian people are very low, and may be equated with the vagrant, so they will treat the workers selfishly like a servant or even more despicable again equated with slaves in ancient times. It is very possible that employers, both in Saudi Arabia and in other countries will treat the workers as they please. That's all because the Indonesian government itself is less able to provide protection to the migrant workers who are abroad. The government, in fact had made regulations to protect migrant workers abroad, namely Law no. 39 in 2004, but in reality the law is still so weak in providing protection, because as we know that the making of the Act is only based on the spirit of sending Indonesian migrant workers abroad and has not thought too far for its protection. In fact, the country of origin can exercise direct protection in a limited way but in accordance with the signs of international law (Vienna Convention 1963).

The country of origin may provide a protection against its citizens as long as such protection is granted to a situation or case in which its citizens intersect with the recipient country government (not the case of $\mathrm{P}$ To $\mathrm{P}$ ). With such a thing, the Indonesian state cannot provide direct protection against the migrant worker by applying our employment law to the employer to the worker who get undue treatment by the employer. The employer who commits such breach of the law may only be processed in accordance with the laws of his country concerning the protection of foreign workers in that country.

There are several international conventions that expressly guarantee the protection of workers. International human rights law establishes the right to life, personal salvation, and the right to be free from torture and other forms of cruel, inhuman and degrading treatment. In the Declaration on the Elimination of Violence against Women, the United Nations stated that the government has an obligation to prevent, investigate and relate to national legislation, punish acts of violence against women, irrespective of whether such acts are committed by the state or individuals ${ }^{6}$. All countries are responsible for addressing the violence faced by workers at every stage of the migration process. In order to enforce their obligations under international human rights law, something must be carried out in accordance with applicable law and institutionalize programs that can prevent and restore such violence, including by punishing perpetrators of violent crime.

\footnotetext{
${ }^{6}$ Suparman marzuki, 2005, arti penting jaminan perlindungan dan penegakan hak-hak pekerja, paper was presented in the training of protection and fulfillment of the rights of Indonesian workers and foreign workers with human rights perspective organized by the Commission on Human Rights on 11-14 December 2005 at Santika hotel Yogyakarta.
} 
Because the protection of Overseas Migrant Workers is only in accordance with the Law applicable in Indonesia alone, then what happens is the various violations committed by the employer to the workers continue to grow without any clear and directed response from the Indonesian government. As a result the overseas migrant workers are in poor working conditions and quality of life, worse yet the Indonesian government which he said ratified the 1990 migrant convention is only limited to discourse alone, we can see from their journey. The agenda to ratify this migrant convention has been included in the National Agenda of National Human Rights (RAN) 1998-2003, RAN-HAM 2004-2009, and RAN-HAM 2010-2014 but until now has not been realized, this happens because there is no target achievement.

The working relationship between the worker and the employer arises from the employment agreement between the migrant worker and the employer abroad, in the work agreement contains the rights and obligations of both parties which have been regulated in the agreement between the Indonesian state and the country where the worker is working. Thus the relationship between the two parties between the workers and employers in the country cannot be separated from the relationship between the two countries. Migrant worker is a weak party, so they need to get greater protection, because in reality there are differences both economically, socially, and psychology in the labor relations between migrant workers and employers. In Law no. 39 of 2004 Article 80 paragraph (1) states the protection during the placement period of overseas migrant workers in doing, among others:

a. Provision of legal assistance in accordance with the provisions of laws and regulations in the country of destination and customary international law;

b. The defense of the fulfillment of rights in accordance with the employment agreement and the legislation in the country of migrant workers are placed.

From the aforementioned clause of the article, it can give an idea that the Indonesian government cannot penetrate the applicable laws and regulations in the country of worker, the government can only provide protection to the worker through consular officers accredited or recognized by the recipient country.

In accordance with Law no. 39 of 2004, Article 95 (2a) concerning the protection and placement of Indonesian workers abroad, and Presidential Regulation no (A) states "BNP2TKI has the duty to placement on the basis of a written agreement between the Government and the Government of the country of the users of the TKI or the user of the Legal Entity in the destination country of placement". BNP2TKI is an institution that has 
been established by the government to implement policies in the field of Indonesian labor in a coordinated and integrated manner.

In order to provide protection to Overseas Workers BNP2TKI undertakes placement based on a written agreement based on $G$ to $G, G$ to $P, P$ to $P^{7}$. In performing its functions and duties BNP2TKI is coordinated by the Minister responsible for manpower affairs, as set forth in Article 4 Presidential Regulation no. It is the Minister of Manpower who is responsible to manage if there is a problem about worker abroad, but we need to know that the foreign affairs of a country there is a separate institution assigned to it, namely the foreign minister. Since there are two institutions in one area of affairs, the two institutions, namely the Minister of Manpower and the Minister of Foreign Affairs must coordinate each other so that there is no overlapping authority. Because there are some institutions related to the protection of migrate workers, it is necessary to establish coordination between BNP2TKI and the Department of Labor and Transmigration, as well as between the Department of Labor and the Department of Foreign Affairs.

The problems of migrant workers generally not only due to violations of the norms of placement and protection of labor migrants, but it also can occur not because of normative violations. While in handling the problem of TKI can only be done based on the existence of complaint or information obtained from result of monitoring problems of worker both inside and outside country.

\section{CONCLUSION}

The numbers of cases of migrant workers abroad need to establish protection that can overcome the problems exist so far related to the placement and protection of migrant workers before leaving, during work and after returning to Indonesia. Therefore, there needs to be mutual coordination between related institutions from the Regional Government, the Department of Manpower and Transmigration, the National Agency for the Placement and Protection of Indonesian Migrant Workers (BNP2TKI), the Department of Foreign Affairs to avoid overlap of authority and mutual tug of power between institutions. From these various labor issues due to the lack of attention to labor issues, especially for developing countries that send their workforce abroad or from the country of work. Lack of attention, lack of protection are not only because the attention of the

\footnotetext{
7 Badan Nasional Penempatan Dan Perlindungan Tenaga Kerja Indonesia (BNP2TKI), 2009, penanganan rekrutmen, pra keberangkatan, monitoring dan penanganan masalah TKI.
} 
overseas labor sending country is focused on domestic problems, but also because the problems of violations in the world of work are more likely to be closed from public access and the dilemma of the labor itself fight for his rights.

As regulated in the Act no. 39 of 2004 Article 6 that the government is responsible for increasing the protection of Indonesian migrant workers abroad, it is necessary for the active role of the government to protect the migrant workers without any pressure from other parties. In order to protect these workers also requires the participation of various parties, such as families of migrant workers, labor organizations, and other parties that exist. In order to provide protection to TKI is not only the duty of the minister of labor alone, but also the duty of the foreign minister. This is in accordance with the sound of Article 19 (b) of Law no. 37 of 1999 on Foreign Relations, namely the representation of the Republic of Indonesia is obliged to provide protection, protection and legal assistance for Indonesian citizens and legal entities abroad in accordance with national legislation and international law and customs.

In accordance with the principle of international law the protection of the law against citizens ceases when such citizens cross the boundaries of the jurisdiction of the state. Protection of Indonesian workers overseas or receiving country is conducted in accordance with international law and applicable law in that country. Forms of state intervention recognized by international law are P1, CA, DP.

\section{BIBLIOGRAPHY}

Ade Maman Marzuki. 2009. Makalah Perlindungan Hukum Tenaga Kerja Migrant Dalam Persfektif Hukum.

Badan Nasional Penempatan dan Perlindungan Tenaga Kerja Indonesia. 2009. Makalah penanganan rekrutmen, pra keberangkatan, manitoring dan penanganan masalah TKI.

Dirjen perjanjian ekonomi dan budaya departemen luar negeri, makalah, peranan departemen luar negeri dalam perlindungan WNI di luar negeri, 2009.

Kompas 26 Nopember 2010.

Masrana Sama. 2006. Makalah in search of a better relations system for Indonesia.

Suara merdeka 19 Nopember 2010.

Suparman Marzuki. 2005. Makalah Arti Penting Jaminan Perlindungan Dan Penegakan Hak-Hak Pekerja. 